\title{
Dynamic changes in T-cell subsets and C-reactive protein after radiation therapy in lung cancer patients and correlation with symptomatic radiation pneumonitis treated with steroid therapy
}

This article was published in the following Dove Press journal:

Cancer Management and Research

\author{
Lu Bai' \\ Bao-Sen Zhou ${ }^{2,3}$ \\ Yu-Xia Zhao ${ }^{4}$ \\ 'Department of Radiation Oncology, \\ First Affiliated Hospital of China Medical \\ University, Shenyang I I000I, People's \\ Republic of China; ${ }^{2}$ Department of \\ Epidemiology, School of Public Health, \\ China Medical University, Shenyang \\ I I0I22, People's Republic of China; \\ ${ }^{3}$ Liaoning Provincial Department of \\ Education, Key Laboratory of Cancer \\ Etiology and Prevention, First Affiliated \\ Hospital of China Medical University, \\ Shenyang II000I, People's Republic of \\ China; ${ }^{4}$ Department of Radiation \\ Oncology, Fourth Affiliated Hospital of \\ China Medical University, Shenyang \\ I 10032, People's Republic of China
}

Objectives: To investigate relationships among serum T-cell subsets, CRP, levels and radiation pneumonitis (RP) in lung cancer patients receiving radiotherapy.

Methods: A case-control study with frequency matching was carried out. The case group comprised 36 lung cancer patients who had developed grade $\geq 2$ RP after thoracic radiotherapy. The control group was 36 patients with lung cancer without RP. Patients in the case group received steroid therapy for 1 month after diagnosis of RP and were followed up for 3 months. T-cell subsets, CRP, and pulmonary function were detected at three time points (onset of RP and 1 and 3 months after diagnosis). Data for the control group were collected 3 months after radiotherapy. Treatment effectiveness was evaluated at 1 and 3 months after diagnosis of RP.

Results: Of the 36 patients in the case group, three with grade5 RP died from respiratory failure. The other 33 cases had all improved with steroid therapy at 3 months after RP diagnosis. In these $33, \mathrm{CD}^{+} \mathrm{T}$-cell quantity, $\mathrm{CD} 4^{+} \mathrm{T}$-cell quantity, and of $\mathrm{CD} 4^{+}: \mathrm{CD} 8^{+}$ratio in T-cell subsets decreased significantly and CRP increased $(P<0.05)$ at the onset of RP compared with the control group. After steroid therapy, $\mathrm{CD} 4^{+} \mathrm{T}$-cell quantity increased significantly compared to before treatment. The same change was seen in $\mathrm{CD} 4^{+}: \mathrm{CD}^{+}$ratio, whereas CRP levels decreased obviously, with treatment effectiveness improved. In addition, with the damage level of RP increased, $\mathrm{CD}^{+} \mathrm{T}$-cell quantity decreased obviously and CRP levels increased accordingly at the onset of RP $(P<0.05)$.

Conclusion: T-cell subsets and CRP may become effective immunological biomarkers for predicting damage from RP and evaluating treatment effectivesness of steroid therapy.

Keywords: T-cell subsets, radiation pneumonitis, steroid therapy, radiotherapy, C-reactive protein

\section{Introduction}

Radiation therapy is widely recognized as an effective treatment choice with both radical and adjuvant application for thoracic carcinoma, such as lung cancer, esophageal carcinoma, and breast cancer. ${ }^{1-3}$ Thoracic radiotherapy is limited by the high radiosensitivity of normal lung parenchyma, and may lead to different degrees of radiation-induced lung injury, which may cause lung fibrosis and pulmonary insufficiency or even threaten life. ${ }^{4,5}$ Although advances in radiation technique increased delivery dosages of target volume and improved the local control of and survival rate
Correspondence: Yu-Xia Zhao

of Radiation Oncology,

Medical University, 4 Eastern Chongshan

Road, Huanggu District, Shenyang

Liaoning I I0032, People's Republic of

China

Tel +862462043519

Email bailucmul983@hotmail.com 
from thoracic tumors with radiotherapy, radiation pneumonitis (RP) has still been a major barrier restricting improvements in thoracic radiation therapy. Clinically significant radiation-induced lung injury has been reported to occur in up to $30 \%$ of lung cancer patients receiving thoracic radiotherapy ${ }^{6}$ and about $5.2 \%-23.8 \%$ with newly developed radiation techniques. ${ }^{7-9}$ There are two types of radiation-induced lung injury with acute RP that occur several weeks to 6 months postirradiation and late lung fibrosis months to years after irradiation. Common symptoms are cough, shortness of breath, fever, and changes in pulmonary function. In most clinical cases, glucocorticoid is used as the primary treatment method and has obtained clinical agreement, but no controlled clinical trials have been reported. The usual initial dose of steroid therapy for symptomatic RP is $30-100 \mathrm{mg}$ per day, gradually reduced each week, and the treatment course lasts about 1 month. Treatment effectiveness is evaluated according to improvements in clinical symptoms, computed tomography (CT) imaging, and pulmonary function.

However, no effective clinical biomarkers for evaluating and predicting treatment effectiveness by steroid therapy has been discovered. Although the pathogenesis of RP remains unclear, research to date has mainly suggested that inflammation and the immune system play a key role, indicating a variety of cytokines and chemokines are involved in the immunological disorder and inflammatory processes of occurrence and development of RP. ${ }^{10-14}$ Dexamethasone has been reported to inhibit the expression of inflammatory or proinflammatory cytokines in bronchoalveolar lavage fluid of irradiated lung, ${ }^{15}$ and may play a protective role in lung injury induced by radiation. In view of these points, we examined dynamic changes in laboratory indices of immunofunction and inflammation (T-cell subsets and CRP) after radiotherapy in lung cancer patients with symptomatic RP treated with steroid therapy, in order to investigate the association of T-cell subsets and CRP for prediction of RPdamages level and evaluation of treatment effectiveness of steroid therapy.

\section{Methods}

\section{Patients and radiation therapy}

This was a case-control study with frequency matching. A total of 36 lung cancer patients with grade $\geq 2$ RP after thoracic 3-D conformal radiotherapy with total dose 50-66 Gy from April 2010 to September 2011 at the First Affiliated Hospital of China Medical University were retrospectively investigated. The control group comprised 36 lung cancer patients without RP after thoracic radiation (followed up for 3 months after radiation therapy) during the same period. All patients had histologically or cytologically confirmed lung cancer, first receipt of pulmonary radiotherapy, Karnofsky performance status $>60$, and expected survival of $>6$ months before radiotherapy. Exclusion criteria were pneumonectomy, severe cardiopulmonary disease, and diabetes. This study was approved and supported by the institutional review board of China Medical University. Written informed consent was obtained from each patient for clinical data. The study was conducted in accordance with the Declaration of Helsinki.

\section{Evaluation of RP}

Physical examination and CT were performed at the onset of RP and 1 and 3 months after diagnosis. Common Terminology Criteria for Adverse Events version 4.0 were used to grade RP: grade 2, symptomatic, not interfering with activities of daily living; grade 3, symptomatic, interfering with activities of daily living, oxygen therapy required; gradeg4, life-threatening, ventilatory support required; and grade 5, severe pneumonitis resulting in death. Physical examination, pulmonary function test, blood test, and CT were performed at the onset of RP and 1 and 3 months after diagnosis. Evaluation was accomplished by two attending radiologists together.

\section{Therapeutic strategy and evaluation after steroid therapy}

Patients with RP were diagnosed when they came to hospital with respiratory symptoms and CT-image changes. All patients in the case group received methylprednisolone therapy after diagnosis of grade $\geq 2 \mathrm{RP}$. The original dosage was $32 \mathrm{mg}$ once a day, with $8 \mathrm{mg}$ decreased weekly for 4 weeks. Treatment effectiveness was evaluated according to improvements in clinical symptoms, CT images, and pulmonary function. Evaluation criteria were divided into effective by steroid (symptoms improved with cough or dyspnea release, temperature decrease, moist rale reduced or disappeared, patchy shadows or obscured glass shadows on CT contracted by half or more than diagnosed) and invalid by steroid (symptoms or signs showed no change or greater seriousness, patchy shadows or obscured glass shadows on CT showed no change or evolved). 


\section{Pulmonary function detection, serum} immunofunction, and CRP measurement

$\mathrm{FVC}, \mathrm{FEV}_{1}$, and lung-diffusing capacity for carbon monoxide (DLCO) were measured. Each parameter is expressed as measured value/predictive value $\times 100 \%$. Blood samples were collected from each patient, including T-cell subsets (absolute quantity of $\mathrm{CD}^{+} \mathrm{T}$ cells, $\mathrm{CD} 4^{+} \mathrm{T}$ cells, and $\mathrm{CD}^{+} \mathrm{T}$ cells and $\mathrm{CD} 4^{+}: \mathrm{CD}^{+}$ratio) by multicolor flow cytometry and serum CRP using chemical luminescence. These indicators were tested at three time points: onset of RP and 1 and 3 months after diagnosis. Blood and pulmonary function from the control group were assessed 3 months after radiotherapy.

\section{Statistical analysis}

We used SPSS 13.0 for statistical analysis. Data ae presented as means $\pm \mathrm{SD}$. Differences between groups were assessed by Student's $t$-test and one-way ANOVA. Statistical significance was defined as $P<0.05$.

\section{Results}

\section{Grading of RP patients and follow-up after steroid therapy}

Patient characteristics are shown in Table 1. Of the 36 RP patients, we had 20 grade 2, 12 grade 3, one grade 4 , and three

Table I Patient characteristics

\begin{tabular}{|l|l|l|l|}
\hline & $\begin{array}{l}\text { Control group } \\
\text { (36 cases) }\end{array}$ & $\begin{array}{l}\text { Case group } \\
\text { (36 cases) }\end{array}$ & P-value \\
\hline Age (years) & $61.28 \pm 9.27$ & $57.75 \pm 8.96$ & 0.105 \\
\hline $\begin{array}{l}\text { Sex } \\
\text { Male } \\
\text { Female }\end{array}$ & $\begin{array}{l}28 \\
8\end{array}$ & 28 & 1 \\
\hline $\begin{array}{l}\text { Smoking } \\
\text { Yes }\end{array}$ & 8 & \\
No & 24 & 23 & 0.804 \\
\hline $\begin{array}{l}\text { Pathology } \\
\text { Adeno- } \\
\text { Squamous- } \\
\text { Small-cell lung } \\
\text { cancer }\end{array}$ & 12 & 13 & \\
\hline $\begin{array}{l}\text { Stage } \\
\text { I }\end{array}$ & 10 & 14 & 0.440 \\
II & 10 & 11 & \\
III & 11 & \\
IV & 7 & 21 & \\
\hline
\end{tabular}

grade 5. In sum, 28 cases were male $(77.8 \%)$ and eight female $(22.32 \%)$. Three cases died from RP during treatment. The other 33 were followed up for 3 months: 24 improved obviously after steroid therapy (at both 1 and 3 months after diagnosis), while nine had no significant $\mathrm{CT}$ changes on $\mathrm{CT}$ at 1 month, but had improved at 3 months after RP diagnosis.

\section{Comparative analysis of indices between case and control groups}

Indices of patients in the case group at diagnosis included peripheral blood $\mathrm{CD}^{+}{ }^{+}$T-cell quantity, $\mathrm{CD} 4{ }^{+}+\mathrm{T}$-cell quantity, and $\mathrm{CD}^{+}: \mathrm{CD}^{+}$ratio. These all decreased significantly $(P<0.01)$ when compared to the control group. $\mathrm{CD} 8^{+}$T-cell quantity was comparable between the case and control groups $(P>0.05)$. CRP levels in the case group increased significantly $(P=0.018$, Table 2$)$.

\section{Dynamic changes in pulmonary function,} immunofunction, and CRP before and after treatment in case group Indices of pulmonary function ( $\mathrm{FVC} \%, \mathrm{FEV}_{1} \%$ and $\mathrm{D}_{\mathrm{LCO}} \%$ ) increased significantly $(P<0.05)$ after steroid therapy, especially at 1 month after diagnosis. Accordingly, pulmonary function further improved at 3 months after diagnosis (Table 3). There was no significant difference in CRP levels at 1 month after diagnosis, but there was asignificant difference at 3 months $\left(P<0.05\right.$, Table 4). $\mathrm{CD}^{+}$T-cell quantity was diminished obviously at the onset of RP before steroid therapy, and increased significantly after treatment. The increase was not significant at 1 month after diagnosis, but was statistically significant at 3 months after diagnosis $(P<0.05)$. The $\mathrm{CD} 4^{+}$: $\mathrm{CD} 8^{+}$ratio increased gradually and significantly with treatment time $(P<0.05)$. There was no significant difference in $\mathrm{CD}^{+} \mathrm{T}$-cell quantity before vs after steroid therapy for RP (Table 4).

\section{Relationship of CRP and T-cell subsets in peripheral blood with grade of RP}

At the onset of RP before steroid therapy, CRP levels in peripheral blood increased gradually as RP grade aggravated, and $\mathrm{CD}^{+}$T-cell quantity decreased accordingly. There were significant differences among the grades $(P<0.01$, Table 5).

\section{Discussion}

Symptomatic RP is one of the most common adverse effects of thoracic tumor radiation therapy. Although the 
Table 2 Indics in case (radiation pneumonitis [RP]) and control (non-RP) groups

\begin{tabular}{|c|c|c|c|c|c|c|}
\hline & & Cases & Control group ${ }^{a}$ & Case group & $\boldsymbol{t}$ & $P$-value \\
\hline CRP, mg/L & & 36 & $10.80 \pm 9.47$ & $28.85 \pm 43.49$ & 2.43 & $0.018^{*}$ \\
\hline T-cell subsets & $\begin{array}{l}\mathrm{CD}^{+} \\
\mathrm{CD}^{+} \\
\mathrm{CD}^{+} \\
\mathrm{CD}^{+}: \mathrm{CD}^{+}\end{array}$ & $\begin{array}{l}36 \\
36 \\
36 \\
36\end{array}$ & $\begin{array}{l}1017.8 \pm 406.7 \\
522.3 \pm 269.6 \\
397.3 \pm 193.8 \\
1.44 \pm 1.06\end{array}$ & $\begin{array}{l}726.8 \pm 450.3 \\
238.3 \pm 175.2 \\
401.5 \pm 298.6 \\
0.71 \pm 0.41\end{array}$ & $\begin{array}{l}2.88 \\
5.30 \\
0.07 \\
3.84\end{array}$ & $\begin{array}{l}0.005^{*} \\
0^{*} \\
0.943 \\
0^{*}\end{array}$ \\
\hline
\end{tabular}

Notes: $* P<0.05$. ${ }^{a}$ Detection at 3 months after radiation therapy; ${ }^{b}$ detection at onset of RP.

Table 3 Pulmonary function at three time points in the case group

\begin{tabular}{|l|l|l|l|l|}
\hline & $\begin{array}{l}\text { Time point } \\
\text { (months after } \\
\text { diagnosis) }\end{array}$ & Cases & Mean \pm SD & P-value \\
\hline FVC\% & 0 & 36 & $67.77 \pm 14.18$ & \\
& 1 & 33 & $76.74 \pm 14.39 *$ & 0.002 \\
& 3 & 33 & $79.13 \pm 13.14^{*}$ & \\
\hline FEV $_{1} \%$ & 0 & 36 & $68.83 \pm 14.04$ & \\
& 1 & 33 & $76.56 \pm 15.40^{*}$ & 0.003 \\
& 3 & 33 & $80.30 \pm 11.84^{*}$ & \\
\hline $\mathrm{D}_{\mathrm{LCO}}$ & 0 & 36 & $55.57 \pm 11.91$ & \\
$\%$ & 1 & 33 & $62.07 \pm 11.82^{*}$ & 0 \\
& 3 & 33 & $64.91 \pm 11.05^{*}$ & \\
\hline
\end{tabular}

Notes: $* P<0.05$ compared with 0 months.

Abbreviation: $D_{L C O}$, lung-diffusing capacity for carbon monoxide.

Table 4 T-cell subtypes at three time points

\begin{tabular}{|c|c|c|c|c|}
\hline & $\begin{array}{l}\text { Time point } \\
\text { (months } \\
\text { after } \\
\text { diagnosis) }\end{array}$ & Cases & Mean \pm SD & $P$-value \\
\hline $\mathrm{CD}^{+}$ & $\begin{array}{l}0 \\
1 \\
3\end{array}$ & $\begin{array}{l}36 \\
33 \\
33\end{array}$ & $\begin{array}{l}726 \pm 450 \\
770 \pm 339 \\
791 \pm 301\end{array}$ & 0.77 \\
\hline $\mathrm{CD}^{+}$ & $\begin{array}{l}0 \\
1 \\
3\end{array}$ & $\begin{array}{l}36 \\
33 \\
33\end{array}$ & $\begin{array}{l}238 \pm 175 \\
332 \pm 217 \\
382 \pm 197 * *\end{array}$ & 0.01 \\
\hline $\mathrm{CD}^{+}$ & $\begin{array}{l}0 \\
1 \\
3\end{array}$ & $\begin{array}{l}36 \\
33 \\
33\end{array}$ & $\begin{array}{l}401 \pm 298 \\
368 \pm 170 \\
392 \pm 187\end{array}$ & 0.83 \\
\hline $\begin{array}{l}\mathrm{CD}^{+}: \\
\mathrm{CD}^{+}\end{array}$ & $\begin{array}{l}0 \\
1 \\
3\end{array}$ & $\begin{array}{l}36 \\
33 \\
33\end{array}$ & $\begin{array}{l}0.7 I \pm 0.41 \\
0.99 \pm 0.73^{*} \\
1.03 \pm 0.4 I^{*}\end{array}$ & 0.024 \\
\hline CRP, g/L & $\begin{array}{l}0 \\
1 \\
3\end{array}$ & $\begin{array}{l}36 \\
33 \\
33\end{array}$ & $\begin{array}{l}28.85 \pm 43.49 \\
18.67 \pm 39.04 \\
3.97 \pm 4.26 * *\end{array}$ & $0.012^{*}$ \\
\hline
\end{tabular}

Notes: $* P<0.05$ compared with 0 months; $* * P<0.01$ compared with I month. mechanism is not clear, it is currently recognized that RP is a complex process involving multiple cytokines and immune and inflammatory factors, causing damage to endothelial cells, parenchymal cells, vasculature, stroma, and interactions with and response of the tissue microenvironment, particularly the effects of inflammatory cytokines and lymphocytes. ${ }^{16,17}$ Nakayama et al reported that radiation can induce accumulation of activated $\mathrm{T}$ cells in the lung in patients with lung cancer. ${ }^{18}$ The percentage of lymphocytes and eosinophils in bronchoalveolar lavage fluid was higher in patients in the radiation group than that in the nonradiation group. Furthermore, the comparison was also seen in the RP group and RP-free group. Steroid therapy has proven effective in radiated organs and tissue for its effect on improving inflammation and immunoimbalance. ${ }^{19-21}$ Although few controlled studies have been reported, steroid therapy for RP has been used in clinics since 1951 and has become the primary treatment for symptomatic RP by clinicians. However, the corresponding clinical biomarkers for predicting and evaluating the treatment effectiveness of steroid therapy for RP are lacking. Our research investigated dynamic changes in immune- and inflammation-factor indicators of RP after treatment by steroids, and demonstrated that immunosurveillance and inflammation-monitoring indicators are related to the severity and treatment effectiveness of RP, which may provide valuable reference for clinical application.

The common fractionated dose in radiation therapy ( $2 \mathrm{~Gy} / \mathrm{F}$ ) is considered immunosuppressive. Lymphocyte subsets have distinct radiosensitivities, ${ }^{22}$ producing a variety of cytokines and proinflammatory factors associated with tissue damage after radiation. ${ }^{23-25}$ Other inflammation-related molecules that regulate or degrade extracellular matrix components are then activated. ${ }^{26}$ Immunological mechanisms lead to RP, due to the main pathological change in RP being lymphatic 
Table 5 CRP and T-cell subtypes with different radiation pneumonitis (RP) grades at RP onset

\begin{tabular}{|l|l|l|l|l|l|}
\hline Grade & Cases & CRP & CD4/ $/ \mathbf{L}$ & CD8/ $/ \mathbf{L}$ & CD4 $^{+}: \mathbf{C D}^{+}$ \\
\hline 2 & 20 & $11.72 \pm 10.69$ & $309.15 \pm 189.82$ & $517.5 \pm 338.88$ & $0.76 \pm 0.50$ \\
3 & 12 & $36.04 \pm 48.82^{*}$ & $171.33 \pm 111.17^{*}$ & $251.7 \pm 141.36^{*}$ & $0.69 \pm 0.21$ \\
$>3$ & 4 & $92.93 \pm 70.50^{* *}$ & $84.50 \pm 39.17^{* *}$ & $270.7 \pm 193.08$ & $0.50 \pm 0.40$ \\
\hline$F$ & 8.73 & 4.98 & 3.98 & 0.70 \\
\hline$P$-value & 0.001 & 0.013 & 0.028 & 0.50 \\
\hline
\end{tabular}

Notes: $* P<0.05$ compared with grade $2 \mathrm{RP} ; * * P<0.01$ compared with grade $3 \mathrm{RP}$.

alveolitis. Robert et al found that unilateral pulmonary radiation caused RP in bilateral lung fields. Unilateral radiation therapy on the chest wall of patients with breast cancer induced bilateral lymphatic alveolitis and large accumulation of activated $\mathrm{CD}^{+} \mathrm{T}$ lymphocytes in bilateral bronchoalvelar lavage fluid. ${ }^{27}$ Cappuccini et al reported that activated $\mathrm{T}$ cells infiltrated lung tissue after radiation by animal models in radiation for pulmonary fibrosis. ${ }^{28}$ In a clinical study to clarify the mechanisms of $\mathrm{RP}, \mathrm{CD}^{+}$and $\mathrm{CD} 8^{+} \mathrm{T}$ cells were more abundant in a lung-radiation group than that in the non-lung-radiation group. ${ }^{18}$ All these studies suggest significant changes in $\mathrm{CD}^{+}$and $\mathrm{CD} 8^{+} \mathrm{T}$ cells after chest radiation. Our study found that $\mathrm{CD}^{+}{ }^{+} \mathrm{T}$ cells, $\mathrm{CD} 4^{+} \mathrm{T}$ cells, and $\mathrm{CD} 4^{+}: \mathrm{CD} 8^{+}$ ratiowere decreased significantly in patients at the time of onset of RP, which suggested that T-cell differentiation and proliferation had changed in patients with RP and cellular immunofunction was inhibited by radiation. After steroid therapy, $\mathrm{CD}^{+} \mathrm{T}$-cell quantity and the of $\mathrm{CD} 4^{+}: \mathrm{CD}^{+}$ratio increased $(P<0.05)$ gradually as treatment was prolonged, indicating that cellular immune function improved after glucocorticoid treatment.

As a pentraxin, CRP has long been employed as a marker of inflammation in clinical practice, reflecting inflammation levels earlier than other clinical indicators. It upregulates the production of inflammation cytokines. ${ }^{29}$ There is a close relationship of CRP with inflammationreaction extent, disease change, and recovery of tissue after injury. ${ }^{30}$ Tsoutsou et al proposed a universal research view of pulmonary injury in the context of cell and molecular biological mechanisms. ${ }^{31}$ In the early phase after radiation, some cytokines are involved in cell injury in pulmonary interstitium and cause early inflammation by autocrine, paracrine, and endocrine means. CRP is the first acute-phase reaction proteinsynthesized by liver cells when tissue injury or inflammation occurs. CRP reflects the total systemic burden of inflammation in several disorders, and has been shown to upregulate the production of proinflammatory cytokines. Serum CRP levels increase significantly in patients with chronic obstructive pulmonary disease. ${ }^{32,33}$ Sanuki et al found that elevated CRP levels may be a possible risk factor for RP and may be associated with increased RP. ${ }^{34}$ In our research, we found that serum CRP levels increased significantly more in the case group than the control group. Furthermore, CRP levels increased gradually as the grade of RP became aggravated. In the RP patients effective by steroid therapy, and the serum CRP levels decreased significantly with the treatment effect improved.

\section{Conclusion}

Our study suggests that T-cell subsets and serum CRP levels may become effective indicators for predicting the occurrence of RP and valuable factors for evaluating radiation-induced lung-injury extent and treatment effectiveness with steroids. However, the present study had several limitations. First, it was retrospective. In addition, the number of participants was limited, which may weaken the plausibility of our results. Whether T-cell subsets and serum CRP levels can become an important factor in assessing the occurrence, development, and treatment effectiveness of RP needs further investigation.

\section{Disclosure}

The authors report no conflicts of interest in this work.

\section{References}

1. De Ruysscher D, Faivre-Finn C, Moeller D, et al. European Organization for Research and Treatment of Cancer (EORTC) recommendations for planning and delivery of high-dose, high precision radiotherapy for lung cancer. Radiother Oncol. 2017;124(1):1-10 (PMID:28666551). doi:10.1016/j.radonc.2017.06.003

2. Xi M, Lin SH. Recent advances in intensity modulated radiotherapy and proton therapy for esophageal cancer. Expert Rev Anticancer Ther. 2017;17(7):635-646 (PMID:28503964). doi:10.1080/14737140.2017. 1331130 
3. Zhong QZ, Wang Z, Tang Y, et al. Prognostic value of sequencing of radiotherapy and chemotherapy following breast-conserving surgery for patients with breast cancer. Zhonghua Zhong Liu Za Zhi. 2017;39(4):308314 (PMID:2855075). doi:10.3760/cma.j.issn.0253-3766.2017.04.015

4. Dreyer J, Bremer M, Henkenberens C. Comorbidity indexing for prediction of the clinical outcome after stereotactic body radiationtherapy in non-small cell lung cancer. Radiat Oncol. 2018;13 (1):213 (PMID:30390700). doi:10.1186/s13014-018-1156-1

5. Ren X, Wang L, Han C, Ren L. Retrospective analysis of safety profile of high-dose concurrent chemoradiotherapy for patients with oesophageal squamous cell carcinoma. Radiother Oncol. 2018;129 (2):293-299 (PMID:30270099). doi:10.1016/j.radonc.2018.09.006

6. Robnett TJ, Machtay M, Vines EF, Mckenna MG, Algazy KM, Mckenna WG. Factors predicting severe radiation pneumonitis in patients receiving definitive chemoradiation for lung cancer. Int $J$ Radiat Oncol Biol Phys. 2000;48:89-94 (PMID:10924976). doi:10.1016/s0360-3016(00)00648-9

7. Zhu Z, Fu X. The radiation techniques of tomotherapy \& intensitymodulated radiation therapy applied to lung cancer. Transl Lung Cancer Res. 2015;4(3):265-274 (PMID:26207214). doi:10.3978/j. issn.2218-6751.2015.01.07

8. Shi S, Zeng Z, Ye L, Huang Y, He J. Risk factors associated with symptomatic radiation pneumonitis after stereotactic body radiation therapy for stage I non-small cell lung cancer. Technol Cancer Res \begin{tabular}{l} 
Treat. 2017;16(3):316-320 (PMID:27516466). doi:10.1177/ \\
\hline
\end{tabular} 1533034616661665

9. Baker R, Han G, Sarangkasiri S, et al. Clinical and dosimetric predictors of radiation pneumonitis in a large series of patients treated with stereotactic body radiation therapy to the lung. Int $J$ Radiat Oncol Biol Phys. 2013;85(1):190-195 (PMID:22929858). doi:10.1016/j.ijrobp.2012.03.041

10. Kainthola A, Haritwal T, Tiwari M, et al. Immunological aspect of radiation-induced pneumonitis, current treatment strategies, and future prospects. Front Immunol. 2017;8:506 (PMID:28512460). doi:10.3389/fimmu.2017.00506

11. Li B, Chen SH, Lu HJ, Tan Y. Predictive values of TNF- $\alpha$, IL-6, IL-10 for radiation pneumonitis. Int J Radiat Res. 2016;14(3):173-179. Available from: http://ijrr.com/article-1-1758-en.pdf. Accessed July 29, 2019.

12. Sprung CN, Forrester HB, Siva S, Martin OA. Immunological markers that predict radiation toxicity. Cancer Lett. 2015;368(2):191-7 (PMID: 25681035). doi:10.1016/j.canlet.2015.01.045

13. Dörthe Schaue ED, Micewicz JA, Cheng G, McBride WH. Radiation and inflammation. Semin Radiat Oncol. 2015;25(1):4-10 (PMID:25481260). doi:10.1016/j.semradonc.2014.07.007

14. Hekim N, Cetin Z, Nikitaki Z, Cort A, Saygili EI. Radiation triggering immune response and inflammation. Cancer Lett. 2015;368 (2):156-63 (PMID: 25911239). doi:10.1016/j.canlet.2015.04.016

15. Wang LP, Wang YW, Wang BZ, Sun GM, Wang XY, Xu JL. Expression of interleukin-17A in lung tissues of irradiated mice and the influence of dexamethasone. ScientificWorldJournal. 2014;2014:251067 (PMID: 24744681).

16. Rodemann HP. Molecular radiation biology: perspectives for radiation oncology. Radiother Oncol. 2009;92:293-8 (PMID:19726094). doi:10.1016/j.radonc.2009.08.023

17. Stewart FA, Dorr W. Milestones in normal tissue radiation biology over the past 50 years: from clonogenic cell survival to cytokine networks and back to stem cell recovery. Int J Radiat Biol. 2009;85:574-86 (PMID:19557600). doi:10.1080/09553000902985136

18. Nakayama Y, Makino S, Fukuda Y, Min KY, Shimizu A, Ohsawa N. Activation of lavage lymphocytes in lung injuries caused by radiotherapy for lung cancer. Int J Radiat Oncol Biol Phys. 1996;34 (2):459-67 (PMID:8567349). doi:10.1016/0360-3016(95)02101-9
19. Michalowski AS. On radiation damage to normal tissues and its treatment. II. Anti-inflammatory drugs. Acta Oncol. 1994;33:139157 (PMID:8204269).

20. Magana E, Crowell RE. Radiation pneumonitis successfully treated with inhaled corticosteroids. Southern Med J. 2003;96:521-524 (PMID:12911197). doi:10.1097/01.SMJ.0000054502.81803.A3

21. Sekine I, Sumi M, Ito Y, et al. Retrospective analysis of steroid therapy for radiation-induced lung injury in lung cancer patients. Radiother Oncol. 2006;80:93-97 (PMID:16820236). doi:10.1016/j. radonc.2006.06.007

22. Provatopoulou X, Athanasiou E, Gounaris A, et al. Predictive markers of radiation pneumonitis. Anticancer Res. 2008;28:2421-32 (PMID: 18751429).

23. Yarnold J, Brotons MC. Pathogenetic mechanisms in radiation fibrosis. Radiother Oncol. 2010;97:149-61 (PMID:20888056). doi:10.1016/j.radonc.2010.09.002

24. Anscher MS, Kong FM, Marks LB, Bentel GC, Jirtle RL. Changes in plasma transforming growth factor beta during radiotherapy and the risk of symptomatic radiation-induced pneumonitis. Int $J$ Radiat Oncol Biol Phys. 1997;370:253-8 (PMID:9069294). doi:10.1016/ S0360-3016(96)00529-9

25. Chen Y, Philip R, Williams J, Hernady E, Smudzin T, Okunieff P. Circulating IL-6 as a predictor of radiation pneumonitis. Int $J$ Radiat Oncol Biol Phys. 2001;49:641-8 (PMID:11172944). doi:10.1016/ s0360-3016(00)01445-0

26. Liu W, Ding I, Chen K, et al. Interleukin 1beta (IL1B) signaling is a critical component of radiation-induced skin fibrosis. Radiat Res. 2006;165:181-91 (PMID:16435917).

27. Roberts CM, Foulcher E, Zaunders JJ, et al. Radiation pneumonitis: a possible lymphocyte-mediated hyper-sensitivity reaction. Ann Intern Med. 1993;118(9):696-700 (PMID:8460855). doi:10.7326/00034819-118-9-199305010-00006

28. Cappuccini F, Eldh T, Bruder D, et al. New insights into the molecular pathology of radiation-induced pneumopathy. Radiother Oncol. 2011;101:86-92 (PMID: 21722981). doi:10.1016/j. radonc.2011.05.064

29. Pasceri V, Willerson JT, Yeh ET. Direct proinflammatory effect of $\mathrm{C}$ reactive protein on human endothelial cells. Circulation. 2000;102:2165-2168 (PMID:11056086). doi:10.1161/01.cir.102. 18.2165

30. Kuo HK, Al Snih S, Kuo YF, Raji MA. Chronic inflammation, albuminuria, and functional disability in older adults with cardiovascular disease: the National Health and Nutrition Examination Survey, 1999-2008. Atherosclerosis. 2012;222:502-508 (PMID:22460050). doi:10.1016/j.atherosclerosis.2012.03.004

31. Tsoutsou PG, Koukourakis MI. Radiation pneumonitis and fibrosis: mechanisms underlying its pathogenesis and implications for future research. Int $J$ Radiat Oncol Biol Phys. 2006;66:1281-1293 (PMID:17126203). doi:10.1016/j.ijrobp.2006.08.058

32. Biljak VR, Rumora L, Cepelak I, et al. Gamma-glutamyltransferase and C-reactive protein in stable chronic obstructive pulmonary disease. Coll Antropol. 2013;37(1):221-7 (PMID:23697277).

33. Karadag F, Kirdar S, Karul AB, Ceylan E. The value of C-reactive protein as a marker of systemic inflammation in stable chronic obstructive pulmonary disease. Eur J Intern Med. 2008;19(2):104-8 (PMID:18249305). doi:10.1016/j.ejim.2007.04.026

34. Sanuki N, Ono A, Komatsu E, et al. Association of computed tomography-detected pulmonary interstitial changes with severe radiation pneumonitis for patients treated with thoracic radiotherapy. J Radiat Res. 2012;53:110-116 (PMID:22302051). doi:10.1269/ jrr.110142 


\section{Publish your work in this journal}

Cancer Management and Research is an international, peer-reviewed open access journal focusing on cancer research and the optimal use of preventative and integrated treatment interventions to achieve improved outcomes, enhanced survival and quality of life for the cancer patient.

The manuscript management system is completely online and includes a very quick and fair peer-review system, which is all easy to use. Visit http://www.dovepress.com/testimonials.php to read real quotes from published authors. 